\title{
New records, names and combinations of scaly tree ferns (Cyatheaceae) in eastern Malesia
}

\author{
F.P. Coritico ${ }^{*}$, V.B. Amoroso ${ }^{1}$, M. Lehnert ${ }^{2}$
}

Key words

Alsophila

Cyatheaceae

Mindanao

New Guinea

Philippines

Sulawesi

threatened

\begin{abstract}
Several scaly tree ferns (Cyatheaceae) from eastern Malesia are transferred from Cyathea s.lat. to other genera: Alsophila roroka from Sulawesi; Alsophila lamoureuxii from New Guinea; Alsophila binayana, A. bisquamata, A. mapahuwensis, A. murkelensis, A. ohaensis, and Sphaeropteris pukuana from Seram. A new name is chosen for Cyathea coriacea, Alsophila katoi, which here is first reported for the Vogelkop Peninsula, New Guinea. Alsophila commutata, a tree fern with branched trunks, is first reported from the Philippines, expanding its original distribution from the Malay Peninsula, Sumatra, and Borneo. A detailed and revised diagnostic description of this species is provided and a second-step lectotype is chosen.
\end{abstract}

Published on 28 June 2017

\section{INTRODUCTION}

The scaly tree ferns (Cyatheaceae) comprise c. 600 species worldwide (Conant et al. 1995, Smith et al. 2006) and occur mainly in the wet tropics and southern temperate regions (Lehnert et al. 2013). The Malesian archipelago is considered the main centre of diversity of scaly tree ferns in the Asian region (Tryon \& Gastony 1975), with many of the 250 species being single island endemics (Holttum 1963, 1964). The majority of species are found in mountain ecosystems at high elevations with high relative humidity (Coritico 2014). The complex taxonomy of the tree ferns, fragmentary collections, inadequate descriptions, and special descriptive vocabulary all contribute to the poor taxonomic knowledge of this group (Lehnert et al. 2013). As a result, many specimen identifications in herbaria are doubtful or erroneous. Adding to the confusion is the fact that for a long time, two rivalling systems of genera existed, in which many species have to bear different epithets. In the treatments covering the Neotropics, a system that formally recognized several genera was used (Tryon 1970, Lellinger 1987), whereas in treatments for the Paleotropics, all genera were united under Cyathea with several subgenera and sections (Holttum 1963, Janssen \& Rakotondrainibe 2006, 2007). Phylogenetic studies (Conant et al. 1995, Korall et al. 2007, Janssen et al. 2008) retrieved most of Holttum's subdivisions as monophyletic groups, and confirmed Tryon's splitting of genera as untenable (Conant 1983, Lellinger 1987). The latest classification proposal (PPG 1 2016) favours the recognition of three morphologically definable, monophyletic genera (Cyathea, Alsophila, Sphaeropteris).

Relatively few new taxa have been described from Asia since Holttum's treatments (Holttum 1963, 1964). For one reason, Holttum already dealt with a high number of species described for the region and was able to disseminate his insights in concise descriptions. He also took into account the little understood morphological variability of the taxa, defining some species

\footnotetext{
Center for Biodiversity Research and Extension in Mindanao (CEBREM), Central Mindanao University, Musuan, Bukidnon, The Philippines.

2 Nees-Institut für Biodiversität der Pflanzen, Rheinische-Friedrich-Wilhelms Universität Bonn, Meckenheimer Allee 170, D-53115 Bonn, Germany.

* corresponding author e-mail: cfulgent@gmail.com.
}

relatively loosely. This means that using Holttum's treatments, a name can be applied to a specimen in most cases. Only in areas with low tree fern diversity and when a species is morphologically unique (Lu 1998, Takeuchi 2007), taxonomists felt confident enough to describe species as new to science.

Another reason is the difference in accessibility of the mountains of the island archipelagos in the Malesian region compared to, for example, those of South America. In South America most people live in the mountains, thus exploration of this biodiversity hotspot can rely on relatively good infrastructure, allowing comparatively quick transportation on ever-improving roads between towns. In Indonesia and the Philippines, the settlements are concentrated near the shores of the islands and the mountains form the neglected hinterland. Getting from island to island, and from the shores to the mountains consumes much more time and resources, resulting in fewer field trips and few discoveries. As the rather sporadic explorations of the interior of Sulawesi, the Moluccas and New Guinea demonstrate (Hovenkamp \& De Joncheere 1988, Kato 1990, Lehnert 2016), the Malesian region still harbours many undescribed species. In the Philippines, there is a total of 40 accepted species of scaly tree ferns (Holttum 1963). Mindanao and Luzon Islands have the highest species richness with 20 species each (Coritico 2014) but there are areas that have remained unexplored until recently. Mount Kiamo is one of the remaining mountain ecosystems in the province of Bukidnon in Mindanao island (N08 $\left.{ }^{\circ} 15.301^{\prime} \mathrm{E} 125^{\circ} 09.321^{\prime}\right)$ with the highest point of $1760 \mathrm{~m}$; Mt Limbawon is part of the central cordillera on the island of Mindanao together with the Pantaron range (Gronemeyer et al. 2014). It was here in June 2014 and July 2015, respectively, where FPC and VBA collected a species of scaly tree fern of a unique appearance previously not known among Philippine tree ferns. The plants, which had a highly branched stem and weakly but notably dimorphic fronds, were identified as Cyathea recommutata Copel. (1909) (Alsophila commutata Mett.), a species hitherto only known from the Malay Peninsula, Sumatra, and Borneo. Despite its relatively wide distribution, there is little information about its habit and ecology.

We take the new record for the Philippines as occasion to present a more detailed description of Alsophila commutata, con- 
solidate its typification and provide new combinations and names for species still kept under a broadly defined genus Cyathea.

\section{TAXONOMIC TREATMENT}

Alsophila binayana (M.Kato) Lehnert \& Coritico, comb. nov.

Cyathea binayana M.Kato (1990) 371. - Type: Kato et al. C-3841 (holo Tl; iso BO, L), Indonesia, Central Seram, Manusela National Park, along trail between Wae Huhu and Owae Puku in Mt Binaya, $2800 \mathrm{~m}$.

Distribution — Indonesia (Seram).

Alsophila bisquamata (M.Kato) Lehnert \& Coritico, comb. nov.

Cyathea bisquamata M.Kato (1990) 376. - Type: Kato et al. C-14123 (holo $\mathrm{TI}$; iso BO, L), Indonesia, Central Seram, Manusela National Park, near Muselleinan Pass, in lower montane forest, $700 \mathrm{~m}$.

Distribution — Indonesia (Seram).

\section{Alsophila katoi Lehnert \& Coritico, nom. nov.}

Cyathea coriacea M.Kato (1990) 376, not Cyathea coriacea (Rosenst.) Domin (1929) 262 = Alsophila coriacea Rosenst. (1914) 50. — Type: Kato et al. C-3505 (holo TI; iso BO, K, KYO, L, MO), Indonesia, Central Seram, Manusela National Park, along a trail between Wae Ansela and Wae Huhu, in middle montane forest, 1290-2000 m.

\section{Distribution — Indonesia (Seram, Papua Barat).}

Specimen examined. Indonesia, Papua Barat (West Papua) Province, Manokwari, Dist. Oransbari, Arfak region, Mt Iwom, S1²0.7' E13407.6', $1730 \mathrm{~m}$, primary mountain forest, with Myrtaceae and Lithocarpus sp., 12 Mar. 2011, Lehnert 2489 (BOG, STU, Z).

Alsophila lamoureuxii (W.N.Takeuchi) Lehnert \& Coritico, comb. nov.

Cyathea lamoureuxii W.N.Takeuchi (2007) 148, f. 2-3, map. - Type: Takeuchi, Ama, Siga \& Kavua 16190 (holo LAE; iso A, L), Papua New Guinea, Morobe Province, Siboma Bay, 50 m, 25 Apr. 2002.

Distribution - E Papua New Guinea.

Alsophila mapahuwensis (M.Kato) Lehnert \& Coritico, comb. nov.

Cyathea mapahuwensis M.Kato (1990) 373. - Type: Kato et al. C-11697 (holo TI; iso BO, L, MO), Indonesia, Central Seram, Manusela National Park, along trail from Wae Nua to Gunung (Mt) Mapahawe, near Saunulu, in mossy forest on mountain ridge, 880-1010 m.

Distribution — Indonesia (Seram).

Alsophila murkelensis (M.Kato) Lehnert \& Coritico, comb. nov.

Cyathea murkelensis M.Kato (1990) 373. - Type: Kato et al. C-12807 (holo $\mathrm{TI}$; iso BO, L), Indonesia, Central Seram, Manusela National Park, along trail (Jalan Pipileina) from Gunung Sinaunia to Marraina in the Murkele mountain range, on steep slope in deep shade in montane forest, 2000-2190 m.

Distribution — Indonesia (Seram).

Alsophila ohaensis (M.Kato) Lehnert \& Coritico, comb. nov.

Cyathea ohaensis M.Kato (1990) 378. - Type: Kato M et al. C-11773 (holo $\mathrm{TI}$; iso BO, K, KYO, L, MO), Indonesia, Central Seram, Manusela National Park, along trail (Jalan Lelesiru) to Gunung (Mt) Ohae, in light shade in Cyathea-mixed sparse forest, 400-990 m.

Distribution — Indonesia (Seram).
Alsophila roroka (Hovenkamp) Lehnert \& Coritico, comb. nov.

Cyathea roroka Hovenkamp in Hovenkamp \& De Joncheere (1988) 397. - Type: Hennipman E 5286 (holo L 3 sheets (L0051390, L0051391, L0051392); iso K (K000721210), U (U0007312), US (US00604360)), Indonesia, Sulawesi Tengah, Roroka Timbu, Mountain Forest, 2000 m, 11 May 1979.

Distribution — Indonesia (Sulawesi).

Sphaeropteris pukuana (M.Kato) Lehnert \& Coritico, comb. nov.

Cyathea pukuana M.Kato (1990) 381. - Type: Kato M. et al. C-1530 (holo $\mathrm{TI}$; iso $\mathrm{BO}, \mathrm{L})$, Indonesia, Central Seram, Manusela National Park, along a trail between Owae Huhu and the summit of Gunung (Mt) Owae Puku, northeast of $\mathrm{G}$. Binaya, $2800 \mathrm{~m}$.

Distribution — Indonesia (Seram).

Alsophila commutata Mett. - Fig. 1; Map 1

Alsophila commutata Mett. (1863) 53. - Cyathea recommutata Copel. (1909) 36, nom. nov. for Alsophila commutata Mett., not Cyathea commutata Spreng. (1804) 146, t. 3, f. 32. - Gymnosphaera recommutata (Copel.) Copel. (1947) 98, nom. superfl. - Type: Cuming 396 (lecto K, first step, selected by Holttum (1963) 118, second step (K000636428), selected here; isolecto BM 3 sheets (BM001048020, BM001048021, BM001048022), K 2 sheets (K00636429, K000636430 p.p.), P (P00631684)), Malaysia, Malacca, 1841.

Alsophila heteromorpha Alderw. (1914) 1; (1917) 56; (1920) 129. - Cyathea heteromorpha (Alderw.) Domin (1929) 262. - Type: Matthew 688 (K (K000698822, K000698823, K000698824)), Indonesia, Sumatra, Gunong Sago, 29 Jan. 1913.

Alsophila heteromorpha var. decomposita Alderw. (1920) 129. - Type: Bünnemeijer 3047 (holo L (L0051387); iso K (K000698827), L (L0051386)), Indonesia, Sumatra, Mangani, Sumatra Bi Tinggi bij Mangani, 1100 m, 15 June 1918

Cyathea hewittii Copel. (1911) 134. - Alsophila hewittii Alderw. (1917) 55; C.Chr. (in Christensen \& Holttum 1934) 221. - Type: Brooks \& Hewitt 21 (holo MICH (MICH1190233)), Malaysia, Sarawak, Bongo Mountain.

Cyathea toppingii Copel. (1917) 51; C.Chr. (in Christensen \& Holttum 1934) 220. - Type: Topping 1824 (holo PNH destroyed; iso $\mathrm{GH}-00020915$, NY-00127883, S (S-P-3433), MO (MO255790), US (US00134805), MICH (MICH1190283)), Malaysia, Gurulau Spur, Mount Kinabalu, 21 Nov. 1915. Alsophila subulata Alderw. (1918) 1. - Cyathea subulata (Alderw.) Domin (1930) 164. - Type: Brooks 300.S (holo not located; iso BM 4 sheets (BM001048023, BM001048024, BM001048025, BM001048026)), Indonesia, Sumatra, Lebong Simpang, Benkoelen, Aug. 1917.

Gymnosphaera squamulata auct. non Blume (1828) 243, J.Sm. (1841) 419. - Alsophila squamulata auct. non (Blume) Hook. (1844) 51, Hook. \& Baker (1867) 235.

Tree fern. Trunks erect to decumbent, to $3 \mathrm{~m}$ tall, $10-16 \mathrm{~cm}$ diam, smooth to muricate, with old petiole bases; frond scars not observed, trunk apices not visible, covered with crowded petioles; adventitious buds present, sprouting up to 8 branches.

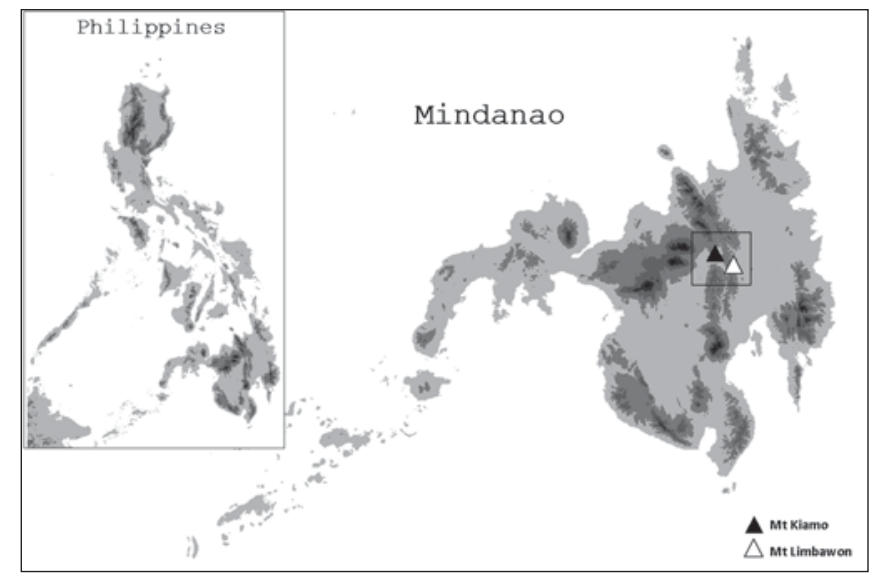

Map 1 Distribution of Alsophila commutata Mett. in the Philippines. 
Fronds to $210 \mathrm{~cm}$ long, ascending, crown funnel shaped. Petioles covered with reddish brown scales from stipe up to rachis and costa 4-6 cm long, smooth, dark purple to black abaxially and adaxially, on each side with a line of discontinuous small narrowly elliptic dark brown pneumatodes; coarsely dissected aphlebiae at base of petiole 4-10 pairs, reflexed to
$5 \mathrm{~cm}$ long, evanescent with age, the strong costae remaining as blunt spines, aphlebiae either separated by gap from rest of the normal pinnae (Sumatra to Borneo) or transient with them (Sumatra, Philippines). Petiole scales marginate with one apical setae (often broken off), concordantly bicolorous, lanceolate to ovate, $8.0-10.0$ by $1.5-2.0 \mathrm{~mm}$, tips weakly heli-
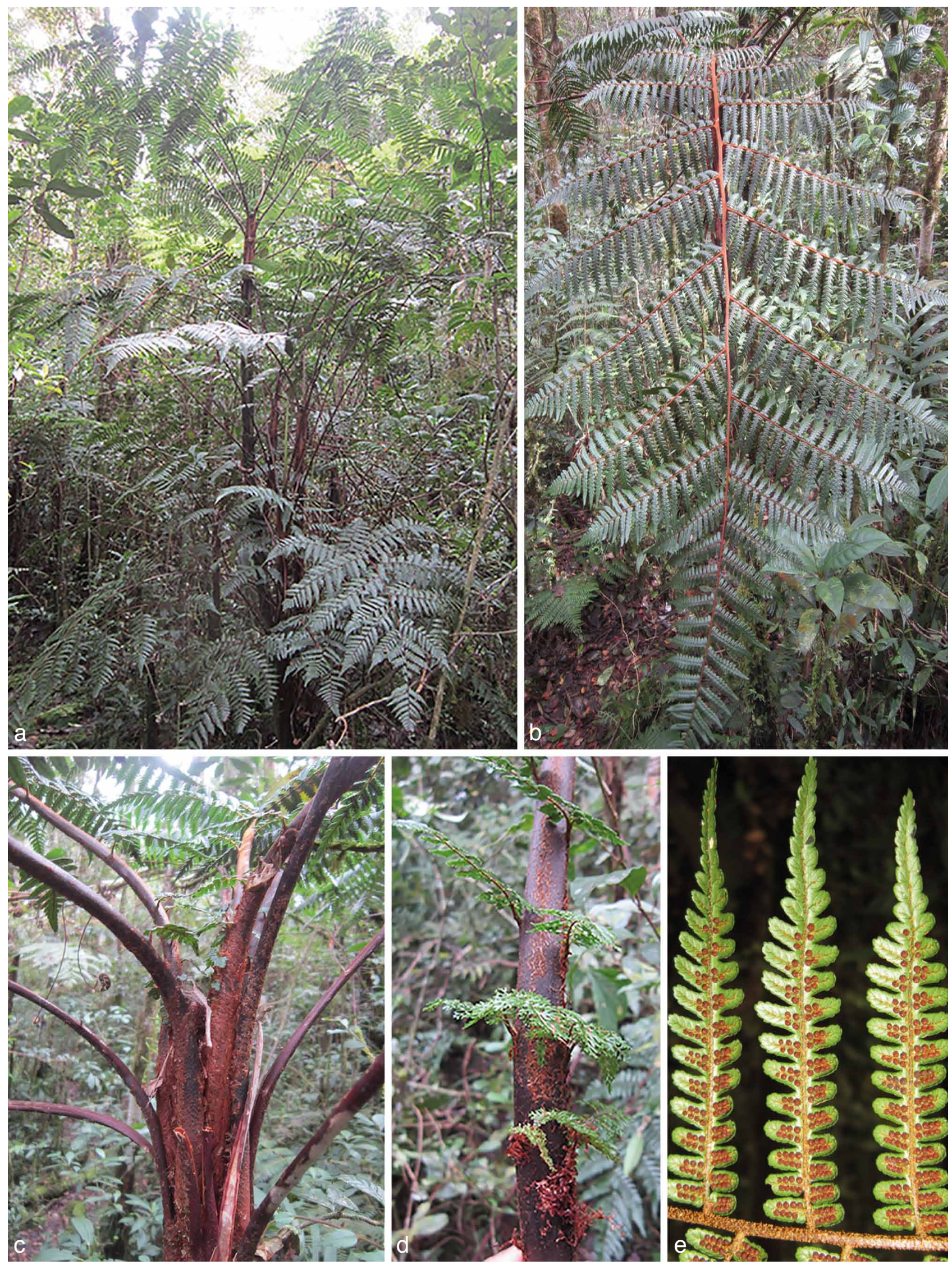

Fig. 1 Alsophila commutata Mett. a. Habit, showing branching trunks; b. lamina outline; c. petiole; d. gradually reduced basal pinnae, lowest one skeletonized; e. sori. - Photos by Fulgent P. Coritico. 
cally twisted, dark brown scale body and margins usually light brown to whitish, not orange or rufescent; petiole scurf red to reddish brown. Laminae to 210 by $75 \mathrm{~cm}$, bipinnate-pinnatifid to tripinnate (when fertile), weakly dimorphic, fertile pinnules slightly contracted, subcoriaceous, ovate to elliptic, basal pinnae gradually reduced, dark green adaxially, pale green abaxially. Pinnae with stalks to $0.5 \mathrm{~cm}$ long, alternate, largest ones $35-40$ by $14-16 \mathrm{~cm}, 11-13$ pairs, costae dark brown to black on both sides. Pinnules stalked $1.0-4.0 \mathrm{~mm}$ long, linear oblong to lanceolate, alternate, largest ones $6.0-7.5$ by $1.3-1.5 \mathrm{~cm}$, cordate to weakly truncate at bases, acute at tips, alternate, 0.7-0.9 mm between the costules. Segments adnate or in lower part free tertiary leaflets, $6.0-7.0$ by $2.5-3.0 \mathrm{~mm}$, oblique to straight with strongly crenate margins, the sinuses somewhat triangular, 1.0-1.5 mm between midveins, sterile segments flat, fertile segments not concave abaxially. Veins free, forked, pale adaxially, dark abaxially; basal basiscopic veins attached to the midveins. Sori near the costules, 4-5 pairs per segment. Indusia absent. Spores tetrahedral, trilete, with straight sides and broadly rounded corners, 35-40 $\mu \mathrm{m}$. Hairs and scales: antrorsely curved, dark reddish brown hairs abundant adaxially on rachises, costae and costules; rachises and costae adaxially with few long, narrow pale brown scales and abaxially with persistent dark brown scales with pale margins; few pale brown bullate scales abaxially on costules and midveins.

Distribution - Malay Peninsula, Sumatra, and Borneo at 600-1500 (-2000) m; on the Philippines only on Mt Kiamo and Mt Limbawon (Mindanao) in montane forests at c. 1600-1700 m.

Specimens examined. INDONESIA, Sumatra, Bukit Tinggi, C. S0 ${ }^{\circ} 18^{\prime} \mathrm{E} 100^{\circ} 21^{\prime}$, 1100 m, 15 June 1918, Bünnemeijer 3049 (K); Sumatra, Atjeh, Gunong Kemiri, c. N3 ${ }^{\circ} 44^{\prime}$ E97²9', 900-1600 m, 22 Aug. 1971, Iwatsuki et al. S.875 (K); Borneo, Kalimantan Timur, Gunung (Mt) Mandam, north of Tabang, C. 600 m, 15 Jan. 1979, Iwatsuki et al. B-2507 (K); Borneo, Kalimantan Timur, Gunung (Mt) Buduk Rian, south of Long Bawan, Krayan, N03 ${ }^{\circ} 50^{\prime}$ E115 42', 1500-1900 m, 18 Aug. 1981, Kato et al. B-11427 (K); East Borneo, Mt Palimasan near Tabang on Belajan River, 800 m, 12 Sept. 1956, Kostermans 12973 (K). - MALAYSIA, Borneo, Sabah, Mt Kinabalu, Mesilau River, 11 Feb. 1964, Chew \& Corner RSNB4331 (K); Sarawak, Mount Dulit, C. N3 ${ }^{\circ} 22^{\prime} \mathrm{E} 114^{\circ} 12^{\prime}, 1230 \mathrm{~m}, 9$ Sept. 1932, Richards 1638 (K). - PHILIPPINES, Mindanao, Bukidnon, Kibalabag, Malaybalay, Mt Kiamo, along the trail going to the peak 1, N08 $15.30^{\prime} \mathrm{E} 12^{\circ} 09.321^{\prime}, 1634 \mathrm{~m}, 14$ June 2014 , Coritico FPC 133 (CMUH-00008408); Mindanao, Bukidnon, Kibalabag, Malaybalay, Pantaron Range, Mt Limbawon, along the trail going to the peak, N08 ${ }^{\circ} 16.264^{\prime}$ E125⒑853', 1698 m, 1 July 2015, Coritico FPC 232 (CMUH-00008580).

Notes - In their descriptions of $A$. commutata, neither Copeland (1909) nor Holttum (1963) did mention the branching of the trunks, although it is the most obvious diagnostic feature of the species in the field. At first, we mistook the Philippine plants for $A$. atropurpurea (Copel.) C.Chr., due to the lack of indusia and the presence of skeletonized basal pinnae, so-called aphlebiae. This character combination defines many species of the Gymnosphaera clade (Korall \& Pryer 2014) morphologically, and $A$. atropurpurea was the only member of this clade hitherto known from the Philippines (Holttum 1963). This is a low number compared to neighbouring islands (Holttum 1963) and the presence of further species was expected when we started our study. One of the expected species was the Bornean Alsophila ramispina Hook., a tree fern described by Copeland (1909) as bearing 3-5 branched black spines to $4 \mathrm{~cm}$ long at the petiole bases, which Holttum (1963) anatomically correctly identified as skeletonized basal pinnae "... all with laminae reduced to a narrow wing along veins and costae". Alsophila commutata differs in having comparatively coarsely dissected basal pinnae with broader remnants of laminar tissue along the free veins. The skeletonized basal pinnae are usually remote from the next regular pinnae in $A$. ramispina and $A$. atropurpurea. Pictures from Malaysia (Piggott 1988) show this gap between skeletonized and normal pinnae also for $A$. commutata but in the
Philippine population, regular pinnae are gradually transient with the skeletonized basal pinnae, without any gap. The same can be found in some specimens from Sumatra (type of $A$. heteromorpha, K000698822). In their account of ferns from Sarawak, Borneo, Tagawa \& Iwatsuki (1966) already pointed out the variability of this character in $A$. commutata.

Alsophila commutata is reliably distinguished from $A$. atropurpurea and $A$. ramispina by having short paraphyses not surpassing the sporangia (vs basally broad paraphyses with narrow filamentous apex surpassing the sporangia in the other two species). Among them, $A$. ramispina further shows the strongest tendency towards dimorphism between fertile and sterile leaves, with fertile pinnules sometimes only half as wide as sterile ones.

The information 'Mt Ophir' as type locality of $A$. commutata (Holttum 1963) comes from the sheet K000636430, where a pinna labelled 'Mt Ophir, Griffith' is mounted below an apex labelled '396. Gymnosphaera squamulata BI., Malacca, Cuming'. The other sheets at $\mathrm{K}$ and those at $\mathrm{BM}$ and $\mathrm{P}$ have only the latter reference. Only the Cuming material should be considered as lectotype material (Holttum 1963), and consequently the information 'Mt Ophir' can be ignored when referring to the type locality.

Copeland (1909) based his Cyathea recommutata on Alsophila commutata Mett. Mettenius (1863) mentioned an 'A. commutata' without indication of an author in his treatment of $A /-$ sophila squamulata, following a comparison with Alsophila glabra Hook.; there is no earlier publication citing this name. Mettenius states that " $A$. commutata (...) deviates in the hardcoriaceous lamina, covered with indument, half-round lobes, veins in lower number, paraphyses equalling the sporangia, partially with apex notably thickened" (pers. translation). Especially the last character is in contrast to his description of A. squamulata, which is stated to have "numerous articulate paraphyses overtopping the sporangia by a little or notably, at apex attenuate or obtuse" (pers. translation). This is still a distinguishing character between the two taxa, additional to the scale type and the dimorphism in the lamina (non-marginate scales, monomorphic lamina in $A$. squamulata vs marginate scales, dimorphic lamina in $A$. commutata). Today, $A$. squamulata is treated as Sphaeropteris squamulata (Blume) R.M. Tryon (Tryon 1970, PPG 1 2016), and A. glabra and A. commutata belong to the Gymnosphaera-clade of Alsophila (Korall \& Pryer 2014).

The placement of the description of $A$. commutata in the original publication (Mettenius 1863) as a short paragraph under A. squamulata, without extra caption and printed in a smaller font makes us doubt that the author intended to describe a new species there. However, since Mettenius (1863) referred to publications of other authors who previously treated material of $A$. commutata as $A$. squamulata and summarized the differences between the two taxa, this constitutes a valid and effective publication of a new species. The collection Cuming 396 and its illustration (Bauer \& Hooker 1842) have to be regarded as original material (Art. 9.3, Melbourne Code; McNeill et al. 2012), which Holttum (1963) correctly identified as type (first-step lectotypification), and from which we designate one sheet as lectotype (second-step lectotypification).

Acknowledgements We would like to thank the Biodiversity Management Bureau (BMB) of the Department of Environment and Natural Resources (DENR) for the permit, Central Mindanao University (CMU) and Center for Biodiversity Research and Extension in Mindanao (CEBREM) for the logistic support and to Captain Shemeul Lagunday and the local guides in Kibalabag for the help during the conduct of the fieldwork. This is part of the research program with funding from the Commission on Higher Education. We thank two anonymous reviewers for their helpful comments. 


\section{REFERENCES}

Bauer F, Hooker WJ. 1842. Genera filicum: 1-6, pl. 1-120. Bohn, London. Blume CL. 1828. Enumeratio Plantarum Javae 2: 99-247. Van Leeuwen, Leiden.

Christensen C, Holttum RE. 1934. The ferns of Mt. Kinabalu. The Gardens Bulletin Straits Settlements 7: 191-317.

Conant DS. 1983. A revision of the genus Alsophila (Cyatheaceae) in the Americas. Journal of the Arnold Arboretum 64, 3: 333-382.

Conant DS, Raubeson LA, Attwood DK, et al. 1995. The relationships of Papuasian Cyatheaceae to New World tree ferns. American Fern Journal 85: $328-340$

Copeland EB. 1909. Ferns of the Malay-Asiatic region 1. Philippine Journal of Science 4: 1-65, pl. 1-21.

Copeland EB. 1911. Bornean ferns. Philippine Journal of Science 6: 133141

Copeland EB. 1917. New species and new genus of Borneo ferns. Philippine Journal of Science 12: 45-65

Copeland EB. 1947. Genera Filicum - the genera of ferns. The Chronica Botanica Co., Waltham, Mass. (Wm. Dawson \& Sons Ltd., London).

Coritico FP. 2014. Morpho-taxonomy and distribution of family Cyatheaceae in Mindanao, Philippines. Graduate School. Central Mindanao University. Domin C. 1929. Pteridophyta. Ceske Akademie, Prague.

Domin C. 1930. The species of the genus Cyathea J. Sm. Acta Botanica Bohemica 9: 85-174.

Gronemeyer T, Coritico FP, Wistuba A, et al. 2014. Four new species of Nepenthes L. (Nepenthaceae) from the central mountains of Mindanao, Philippines. Plants 3, 2: 284-303.

Holttum RE. 1963. Cyatheaceae. Flora Malesiana Series 2, 1: 65-176.

Holttum RE. 1964. The tree ferns of the genus Cyathea in Australasia and the Pacific. Blumea 12: 241-274.

Hooker WJ. 1844. Species filicum I: 1-64, pl. 1-20. Pamplin, London.

Hooker WJ, Baker JG. 1867. Synopsis filicum 6: 209-256. Hardwicke, London.

Hovenkamp PH, De Joncheere GJ. 1988. Additions to the fern flora of Sulawesi. Blumea 33: 395-409.

Janssen T, Bystriakova N, Rakotondrainibe F, et al. 2008. Neoendemism in Madagascan tree ferns results from recent, coincident diversification bursts. Evolution 62: 1876-1889.

Janssen T, Rakotondrainibe F. 2006. A revision of the fern family Cyatheaceae in the Masacarene Island. Adansonia 28, 2: 213-214.

Janssen T, Rakotondrainibe F. 2007. An update of the revision of Cyathea subgen. Alsophila sect. Gymnosphaera (Cyatheaceae) in Madagascar and the Comoros including a discussion of putative hybridization events. Adansonia 29, 2: 195-213.

Kato M. 1990. Taxonomic studies of pteridophytes of Ambon and Seram (Moluccas) collected by Indonesian/Japanese botanical expeditions IV. Tree fern families. Journal of the Faculty of Science, Imperial University of Tokyo, Botany 14: 369-384.
Korall P, Conant DS, Metzgar J, et al. 2007. A molecular phylogeny of scaly tree ferns (Cyatheaceae). American Journal of Botany 94: 873-886.

Korall P, Pryer KM. 2014. Global biogeography of scaly tree ferns (Cyatheaceae): evidence for Gondwanan vicariance and limited transoceanic dispersal. Journal of Biogeography 41: 402-413.

Lehnert M. 2016. Alsophila weidenbrueckii (Cyatheaceae), a new scaly tree fern from Papua New Guinea. Blumea 61: 20-23.

Lehnert M, Coritico FP, Darnaedi D, et al. 2013. Taxonomic and ecologica notes on the Alsophila hornei complex (Cyatheaceae-Polypodiopsida), with the description of the new species A. phlebodes from New Guinea. Systematic Botany 38, 4: 875-886.

Lellinger DB. 1987 '1988'. The disposition of Trichopteris (Cyatheaceae). American Fern Journal 77: 90-94.

Lu SG. 1998. A new species of Alsophila (Cyatheaceae) from Yunnan. Acta Botanica Yunnanica 20, 1: 45-46.

McNeill J, Barrie FR, Buck WR, et al. 2012. International Code of Nomenclature for algae, fungi, and plants (Melbourne Code). Regnum Vegetabile 154. Koeltz Scientific, Books.

Mettenius GH. 1863. Filices, praesertim Indicae et laponicae. Annales Muse Botanici Lugduno-Batavi 1: 53.

Piggott AG. 1988. Ferns of Malaysia in colour. Kuala Lumpur, Tropical Press. PPG 1. 2016. A community-derived classification for extant lycophytes and ferns. Journal of Systematics and Evolution 54: 563-603. doi: https://doi. org/10.1111/jse.12229.

Rosenstock E. 1914. Contribution á l'étude des Ptéridophytes de Colombie. Mémoires de la Société des Sciences Naturelles de Neuchâtel 5, 2 $33-56$, t. 2-6.

Smith AR, Pryer KM, Schuettpelz E, et al. 2006. A classification for extant ferns. Taxon 55: 705-731.

Smith J. 1841. Enumeration Filicum Philippinarum. Journal of Botany, London III: 393-422.

Sprengel KPJ. 1804. Anleitung zur Kenntniss der Gewächse 3: 1-374. Kümmel, Halle.

Tagawa M, Iwatsuki K. 1966. Ferns of Borneo collected by M. Hirano and M. Hotta. 4. Acta Phytotaxonomica et Geobotanica 21: 87-94

Takeuchi W. 2007. Cyathea lamoureuxii (Cyatheaceae): a remarkable new species from the Papuan peninsula of New Guinea. Blumea 52: 147-152.

Tryon RM. 1970. The classification of the Cyatheaceae. Contributions of the Gray Herbarium 200: 3-50.

Tryon RM, Gastony GJ. 1975. The biogeography of endemism in the Cyatheaceae. Fern Gazette (UK), 11(23): 73-79.

Van Alderwerelt van Rosenburgh CRWK. 1914. New or interesting Malayan ferns 6. Bulletin du Jardin Botanique de Buitenzorg II, 16: 1-60, pl. 1-10.

Van Alderwerelt van Rosenburgh CRWK. 1917. Malayan ferns and fern allies. Landsdrukkerij, Batavia.

Van Alderwerelt van Rosenburgh CRWK. 1918. New or interesting Malayan ferns 10. Bulletin du Jardin Botanique de Buitenzorg II, 28: 1-66, pl. 1-10. Van Alderwerelt van Rosenburgh CRWK. 1920. New or interesting Malayan ferns 11. Bulletin du Jardin Botanique de Buitenzorg III, 3: 129-186. 